\title{
TUJUAN PEMBANGUNAN BERKELANJUTAN (TPB) \\ DI KABUPATEN BANDUNG BARAT : PELAJARAN DARI \\ PROGRAM SEKOLAH IBU HEBAT TAHUN 2019-2020
}

\author{
Wahid Noor Jayn \\ Universitas Parahyangan \\ Email: wnoorjayn@gmail.com
}

\begin{abstract}
Abstrak
Penguatan peran perempuan tertuang dalam komitmen global yakni melalui Sustainable Development Goals (SDGs) atau Tujuan Pembangunan Berkelanjutan (TPB). Agenda ini merupakan upaya mengurangi ketimpangan dan ketertinggalan pembangunan dengan melibatkan para pemangku kepentingan. Di Indonesia, TPB diadopsi menjadi Peraturan Presiden No 59 Tahun 2017 Tentang Pelaksanaan Pencapaian Tujuan Pembangunan Berkelanjutan. Keterlibatan pemerintah menjadi hal yang krusial untuk mengatur dan memberikan arahan serta memfasilitasi kepentingan masyarakat. Namun demikian, keterlibatan swasta dan lembaga nonpemerintah juga tidak dapat diabaikan. Pada tahun 2019, BMH (Baitul Maal Hidayatullah) bekerja sama dengan Forum UMKM Kabupaten Bandung Barat menginisiasi program pemberdayaan perempuan yang diberi nama Sekolah Ibu Hebat. Program ini merupakan salah satu kepedulian BMH terhadap kaum perempuan yang menjadi tulang punggung keluarga sehingga dapat meningkatkan kesejahteraan keluarganya melalui pembekalan pelatihan dan keterampilan hingga memberikan bantuan modal usaha. Berdasarkan hasil observasi dan wawancara, penulis menemukan bahwa program pemberdayaan sosial-ekonomi yang dimotori oleh lembaga non-pemerintah ini memiliki tujuan yang sejalan dengan agenda TPB khususnya pemberdayaan perempuan dan ekonomi mikro dan bermuara pada semangat kolaborasi dan kemitraan (partnership). Menariknya, para pihak yang terlibat dalam kegiatan ini justru tidak menyadari bahwa mereka telah menerapkan-sekurang-kurangnya--agenda TPB.
\end{abstract}

Kata Kunci/Keywords : pemberdayaan, TPB/SDGs, perempuan, ekonomi, UMKM.

\section{PENDAHULUAN}

Kesadaran dan komitmen global telah mengikat negara-negara di dunia untuk menjalankan agenda yang disebut dengan Sustainable Development Goals (SDGs) atau Tujuan Pembangunan Berkelanjutan (TPB). Agenda ini mendorong negara anggota Perserikatan Bangsa-bangsa agar melakukan tindakan nyata untuk 
mewujudkan cita-cita dan masa depan yang lebih baik di semua bidang kehidupan. TPB dituangkan ke dalam 17 poin utama. Krisis dan ketimpangan di bidang sosial, ekonomi, degradasi lingkungan hingga kelaparan pada beberapa dekade memberikan pemahaman bagi para pemangku kepentingan untuk bertindak melalui kerangka TPB.

Konsep sustainable berangkat dari perlunya meningkatkan kualitas kehidupan sembari menjaga ekosistem penunjang kehidupan seperti kelestarian alam, keadilan sosial dan ekonomi, tersedianya kesempatan dan akses yang lebih luas kepada kaum perempuan dan seterusnya. Sebagai negara yang aktif dalam forum internasional, Indonesia turut mendukung kesepakatan global tersebut demi mewujudkan pembangunan yang adil, damai dan berkelanjutan. TPB diadopsi menjadi Perpres No 59 Tahun 2017 tentang Pelaksanaan Pencapaian Tujuan Pembangunan Berkelanjutan. TPB merupakan sebuah gagasan pembangunan yang mengedepankan aspek berkelanjutan yang disepakati para pemimpin negara di dunia pada tahun 2015. Agenda TPB pada prinsipnya mengacu pada 5P (people, planet, prosperity, peace, partnership). Cakupan TPB yang luas, 17 tujuan dengan 169 target, memberikan perspektif baru mengenai definisi "pembangunan" yang berlaku universal, bukan hanya menargetkan negara berkembang, melainkan negara maju juga termasuk di dalamnya (Bappenas, 2017)

Kebijakan di tingkat nasional tentu menjadi acuan bagi pembuatan kebijakan di tingkat daerah. Pembangunan berkelanjutan di daerah, yang diejawantahkan melalui RPJMD, memberikan arah dan pedoman bagi terselenggaranya pelayananan dari pemerintah yang dapat dirasakan manfaatnya dan memberikan dampak bagi masyarakat dalam rangka meningkatkan kesejahteraan sosial suatu lingkungan wilayah/daerah dalam jangka waktu tertentu (Ranwal RPJMD KBB, 2018). Cetak biru (blueprint) ini menjadi kerangka bagi pemerintah daerah dalam merumuskan kebijakan untuk kepentingan masyarakat di wilayah administratifnya. Namun, tidak jarang bahwa kebijakan pembangunan hanya menyentuh aspek pembangunan fisik saja, padahal pembangunan dan peningkatan kapasitas sumber daya manusia tidak kalah penting. 
Dari ketujuhbelas poin yang menjadi agenda TPB yang sebetulnya saling terkait, poin ke-5 (Mencapai kesetaraan gender dan memberdayakan perempuan) dan ke-8 (Mempromosikan pertumbuhan ekonomi yang berkelanjutan dan inklusif, lapangan pekerjaan yang layak untuk semua) telah menarik perhatian penulis untuk meneliti bagaimana kedua tujuan ini diimplementasikan di Indonesia, lebih khusus dilaksanakan di Kabupaten Bandung Barat (KBB). TPB dapat diimplementasikan dalam berbagai bidang yang berkenaan dengan kehidupan masyarakat. Salah satu bidang atau sektor yang dapat menjadi pendorong terwujudnya TPB adalah sektor UMKM.

Penduduk di Kabupaten Bandung Barat yang mencapai 1.7 juta jiwa, relatif berimbang dalam hal jumlah penduduk laki-laki dan perempuan, masing-masing 861.529 jiwa dan 838.367 jiwa (BPS Jawa Barat, 2019). Jika dilihat dari komponen Indeks Pemberdayaan Gender (IPG), sumbangan pendapatan perempuan terhadap pendapatan rumah tangga di Kabupaten Bandung Barat sebesar 32,94\% di tahun 2018 (BPS Jawa Barat, 2019). Sementara jumlah perempuan yang terlibat aktif dalam aktivitas ekonomi khususnya UMKM mencapai 78\% (Diskop UKM KBB, 2019). Hingga tahun 2019, UMKM di Kabupaten Bandung Barat yang terdaftar di Dinas Koperasi dan UKM setempat berjumlah 12.233, tersebar di 16 kecamatan dengan Kecamatan Ngamprah menjadi kecamatan yang paling banyak dengan jumlah 1.890 (Diskop UKM KBB, 2019). Jumlah tersebut terdiri dari lima sektor usaha, yakni fesyen, kuliner, kriya, jasa, warungan dan lainnya. Sebanyak 11.603 atau $94.85 \%$ masuk ke dalam kriteria usaha mikro, 577 atau $4.72 \%$ usaha kecil, dan 53 atau $0.43 \%$ usaha menengah.

Pengimplementasian agenda TPB memerlukan pemahaman komprehensif dan proses yang boleh jadi tidak sebentar. Karena itu, TPB perlu diupayakan oleh semua pihak termasuk lembaga non-pemerintah. Program Sekolah Ibu Hebat (SIH) yang diinisiasi oleh Baitul Maal Hidayatullah dengan menggandeng PT. Paragon dan Forum UMKM Kabupaten Bandung Barat menjadi fenomena yang cukup menarik perhatian penulis karena program ini memadukan pemberdayaan perempuan dan ekonomi, yang mana hal tersebut berkaitan dan sejalan dengan agenda TPB. Tulisan ini mencoba mencari tahu faktor apa saja yang mendasari 
program Sekolah Ibu Hebat? Mengapa kaum perempuan menjadi subjek dari kegiatan ini? Apa tujuan utama dari program ini? Adakah keterkaitan program SIH di KBB dengan agenda TPB? Bagaimana pula jalinan kemitraan antara pemerintah daerah, Forum UMKM dan BMH?

Dalam artikel ini, penulis menggunakan beberapa referensi sebagai tinjauan pustaka. Tulus Tambunan (2017), dalam tulisannya menjelaskan bahwa kegiatan ekonomi, melalui usaha mikro, kecil, dan menengah, yang dijalankan oleh kaum perempuan terus berkembang. Atas dasar itulah kebijakan pemerintah untuk mempromosikan perempuan menjadi hal yang penting. Kepemilikan usaha dalam skala mikro dan kecil oleh perempuan, menurut Tambunan, sedikitnya terdiri dari dua alasan. Pertama, dalam menjalankan usaha mikro tidak membutuhkan modal yang besar, tidak memerlukan teknologi yang canggih atau keterampilan tinggi, karena pada umumnya mereka menghasilkan produk yang proses dan pengolahannya sederhana seperti makanan atau kerajinan tangan. Kedua, karena proses dan pengolahan yang sederhana, kegaitan ini bisa dilakukan oleh siapapun termasuk ibu tumah tangga.

Lebih lanjut, Tambunan mendapati bahwa kaum perempuan yang menjalankan bisnisnya dilandasi oleh dua motif: semangat kewirausahaan dan faktor ekonomi. Dengan metode survei dan wawancara dari 108 responden, 56 orang memberikan jawaban 'terpaksa' menjalankan bisnis hanya karena faktor ekonomi untuk sekadar bisa bertahan hidup dan 40 lainnya menjawab karena berniat untuk menjadi seorang pengusaha. Pada pertanyaam lainnya, responden juga menjawab bahwa mereka tidak pernah mengikuti program yang diinisiasi oleh pemerintah, misalnya pelatihan vokasional/keterampilan. Beberapa diantaranya menjawab tidak butuh, beberapa lainnya menjawab memerlukan akses ke bahan baku alih-alih pelatihan, dan sebagain lainnya menjawab belum pernah mendengar informasi program dari pemerintah. Pada bagian akhir, Tambunan menyimpulkan berkembangnya wirausaha perempuan khususnya pasca krisis 1997/1998 semestinya mampu menarik perhatian pemerintah dalam rangka pembangunan ekonomi berkelanjutan. 
Tulisan selanjutnya dari Esther Dulfo (2012) yang menjelaskan bahwa terdapat hubungan dua arah antara pembangunan ekonomi dan pemberdayaan perempuan. Kemiskinan dan kurangnya kesempatan menyebabkan adanya ketidaksetaraan gender. Melalui pembangunan ekonomi dan berkurangnya kemiskinan akan memberikan dampak bagi kaum perempuan dalam dua aspek : kehidupan masyarakat akan semakin membaik, termasuk perempuan di dalamnya, dan ketidaksetaraan antara laki-laki dan perempuan akan berkurang seiring dengan meningkatnya taraf hidup dan terbukanya kesempatan bagi perempuan untuk beraktualisasi. Kedua hal tersebut akan menjadi keuntungan bagi pembangunan

Menurut Dulfo, pada hubungan pertama, pembangunan ekonomi, didasari oleh sedikitnya lima argumen : Pertama, pengurangan kemiskinan dengan penyediaan akses yang memadai bagi semua warga. Pada sebuah studi, ditemukan terdapat perbedaan perlakuan pada anak laki-laki dan perempuan dalam kasus tertentu, misalnya pemberian nutrisi atau ketika anak sakit. Kedua, pembangunan mampu mengurangi risiko kematian ibu dan anak melalui tersedianya fasilitas memadai. Ketiga, pembangunan memberikan harapan bagi kaum perempuan untuk menggali potensi mereka melalui kesempatan yang tersedia. Keempat, dengan tersedianya kesempatan, mereka dapat menentukan pilihan untuk melakukan apapun. Misalnya, menjadi pengusaha, menjalankan bisnis yang bahkan tanpa perlu ke luar rumah. Kelima, pembangunan ekonomi memberikan kesempatan bagi perempuan untuk mengakses lembaga keuangan, hak kepemilikan tanah, dan sebagainya.

Di sisi lain, pemberdayaan perempuan juga memberikan dampak bagi pembangunan. Pemberdayaan bukan hanya sekadar "keharusan" tetapi memang "demikian adanya" sehingga korelasi antara pembangunan dan pemberdayaan berjalan positif. Misalnya, dengan tersedianya akses pendidikan dan kesehatan, tingkat literasi akan membaik, pendapatan keluarga akan meningkat, kemiskinan akan berkurang, risiko kematian ibu dan anak bisa diminimalisi, sehingga "peran" perempuan semakin besar bagi pembangunan. Oleh karena itu, menurut Dulfo, dibutuhkan tidak hanya sekadar pembangunan ekonomi melainkan diimbangi 
dengan kebijakan yang dapat memberikan ruang bagi perempuan untuk berkontribusi bagi pembangunan.

Dalam tulisan lain, Bina Agarwal (2018) menjelaskan poin kelima TPB, yakni kesetaraan gender, memiliki potensi untuk mewujudkan ketahanan pangan. Ia berpendapat bahwa dengan terbukanya kesempatan bagi perempuan untuk bisa mengakses kepemilikan lahan, perbankan, dan sumber daya alam akan mampu meningkatkan ketahanan pangan nasional. Keterlibatan perempuan dalam hal ini bukan hanya sekadar 'mengakses' melainkan merumuskan, memutuskan atau mengambil kebijakan serta mengelola sumber daya alam. Hal ini merupakan suatu penafsiran dari target TPB 5.5. Selain itu, yang tidak kalah penting ialah keterkaitan antara satu poin TPB dengan poin lainnya yang mana peran perempuan baik langsung maupun tidak langsung (dalam hal persoalan pangan / food security) tidak bisa dihindarkan. Misalnya, pada poin 1 dan 2 yakni pengurangan kemiskinan dan zero hunger. Dalam kasus lainnya ialah poin 13, 14, 15. Hal ini didukung oleh kenyataan kepemilikan lahan oleh perempuan kurang dari $40 \%$ di negara-negara berkembang. Oleh karena itu, tulisan Agarwal membuka pemahaman baru bagi terwujudnya TPB melalui pendekatan kesetaraan gender.

\section{PEMBAHASAN}

\section{A. TPB di Kabupaten Bandung Barat}

Agenda Sustainable Development Goals (SDGs) atau Tujuan Pembangunan Berkelanjutan (TPB) merupakan salah satu agenda global dalam upaya mengurangi ketimpangan dan ketertinggalan pembangunan dengan melibatkan para pemangku kepentingan. Di Indonesia, komitmen ini dituangkan ke dalam Peraturan Presiden No 59 Tahun 2017 Tentang Pelaksanaan Pencapaian Tujuan Pembangunan Berkelanjutan. Keterlibatan pemerintah menjadi hal yang krusial khususnya dalam kerangka regulasi dan perangkat peraturan lainnya. Akan tetapi peran swasta dan organisasi kemasyarakatan juga tidak kalah penting. Dalam scope provinsional, peraturan ini dipertegas melalui Pergub Jawa Barat No. 18 Tahun 2018 Tentang Rencana Aksi Daerah (RAD) Tujuan Pembangunan Berkelanjutan/Sustainable Development Goals Daerah Provinsi Jawa Barat. Mengacu pada peraturan tersebut, 
RAD TPB/SDGs adalah dokumen rencana kerja Daerah Provinsi untuk melaksanakan berbagai kegiatan yang secara langsung dan tidak langsung mendukung pencapaian TPB/SDGs yang sesuai dengan sasaran pembangunan Daerah Provinsi tahun 2018-2023 yang tertuang dalam Rencana Pembangunan Jangka Menengah Daerah (RPJMD) Provinsi Jawa Barat tahun 2018-2023. Pada tataran pemerintah daerah Kabupaten Bandung Barat, kebijakan ini dituangkan melalui Rancangan Awal (Ranwal) RPJMD Tahun 2018-2023 di mana pembangunan berkelanjutan mendapatkan porsi di dalam rencana pembangunan daerah.

Dalam bidang ekonomi, Pemerintah Daerah KBB memiliki misi untuk mewujudkan kesejahteraan sosial dan ekonomi masyarakat, yang ditandai oleh sistem perekonomian yang berkeadilan dan berdaya saing global, disertai dengan terwujudnya sarana dan prasarana ekonomi yang memadai, tercapainya penguasaan, pengembangan, dan pemanfaatan ilmu pengetahuan serta teknologi untuk mendukung pembangunan ekonomi yang berkelanjutan. Lebih jauh dalam memajukan UMKM, Pemda Bandung Barat memiliki strategi peningkatan kompetensi kewirausahaan, peningkatan produktivitas, pemanfaatan hasil inovasi dan penerapan teknologi dalam sistem usaha yang sehat. Pengembangan UMKM dilakukan secara terintegrasi dengan pengembangan agroindustri dan pariwisata, penyediaan dana penjamin eksport, menjalin kemitraan dengan pengusaha besar maupun dengan sesama UMKM, menghimpun kelompok usaha UMKM sejenis dalam badan hukum koperasi, mendorong dan memfasilitasi perkembangan koperasi (RPJMD KBB, 2018)

Pembangunan (development) didefiniskan tidak hanya terbatas pada terminologi ekonomis saja melainkan pada perspektif yang lebih luas, meliputi pembangunan manusia termasuk di dalamnya sosial, politik, budaya, lingkungan dengan prinsip kesetaraan dan non-diskriminasi, serta partisipasi aktif masyarakat dalam prosesnya (UN Declaration on the Right to Development, 1986). Keterlibatan masyarakat bukan hanya sekadar menjadi objek tetapi dipandang sebagai subjek yang, baik secara langsung maupun tidak langsung, memberikan pengaruh bagi proses pembangunan. Keterlibatan masyarakat dalam pembangunan 
tergantung dari corak dan pola kebijakan apa yang diambil oleh pemerintah serta bagaimana mereka memandang kapabilitas masyarakat dan sejauh mana mereka akan berdampak pada pembangunan (Nussbaum, 2000 : 86-88), termasuk perempuan di dalamnya. (Harcourt ed., 2016 Sara de Jong:98).

Sementara itu, pemberdayaan perempuan (women empowerment) juga memegang peranan dalam proses percepatan pembangunan. Pemberdayaan perempuan merupakan proses yang ditujukan untuk mengubah relasi gender, melalui individu atau kelompok, mengembangkan kesadaran tentang subordinasi perempuan dan membangun kapasitas mereka. Konsep pemberdayaan perempuan bukan berarti perempuan mengambil alih kendali yang sebelumnya dipegang oleh laki-laki, melainkan mengakomodir dan memberikan kesempatan yang sama kepada perempuan (Baden, Reeves, $2000: 35$ ).

Tabel di bawah ini merupakan penjabaran tujuan dan sasaran strategis yang hendak dicapai oleh Pemda KBB. Penulis memberikan perhatian pada poin pemberdayaan masyarakat dan pengarusutamaan gender, yang mana erat kaitannya dengan pembahasan dalam tulisan ini.

Tabel Kerangka Logis Pencapaian Misi 1

Pembangunan Bandung Barat 2018-2023

\begin{tabular}{|c|c|c|c|}
\hline \multirow{2}{*}{ Misi 1} & Tujuan & Sasaran Strategis & \multirow{2}{*}{$\begin{array}{c}\text { Indikator Sasaran Strategis } \\
\text { Dampak yang diinginkan }\end{array}$} \\
\hline & \multicolumn{2}{|c|}{ Apa yang ingin diubah } & \\
\hline \multirow{3}{*}{$\begin{array}{l}\text { Meningkatkan } \\
\text { cakupan dan } \\
\text { kualitas } \\
\text { layanan } \\
\text { pendidikan, } \\
\text { kesehatan dan } \\
\text { pelayanan } \\
\text { dasar bagi } \\
\text { masyarakat } \\
\text { luas lainnya } \\
\text { dalam rangka } \\
\text { membangun } \\
\text { sumber daya } \\
\text { manusia yang } \\
\text { berkualitas }\end{array}$} & $\begin{array}{l}\text { Peningkatan pelayanan } \\
\text { pendidikan yang } \\
\text { berkualitas, merata dan } \\
\text { dapat dijangkau oleh } \\
\text { seluruh masyarakat }\end{array}$ & $\begin{array}{l}\text { Meningkatnya } \\
\text { layanan pendidikan }\end{array}$ & $\begin{array}{l}\text { Indeks pendidikan } \\
\text { Angka Melanjutkan (AM) } \\
\text { dari SD/MI ke SMP/MTs } \\
\text { Angka Melanjutkan (AM) } \\
\text { dari } \quad \text { SMP/MTs } \\
\text { SMA/SMK/MA }\end{array}$ \\
\hline & $\begin{array}{l}\text { Peningkatan pelayanan } \\
\text { kesehatan yang } \\
\text { berkualitas, merata dan } \\
\text { dapat dijangkau oleh } \\
\text { seluruh masyarakat }\end{array}$ & $\begin{array}{l}\text { Meningkatnya akses } \\
\text { masyarakat terhadap layanan } \\
\text { kesehatan }\end{array}$ & $\begin{array}{l}\text { Indeks kesehatan } \\
\text { Cakupan KB aktif }\end{array}$ \\
\hline & $\begin{array}{lr}\text { Pemenuhan } & \text { pelayanan } \\
\text { kebutuhan } & \text { dasar } \\
\text { lainnya } & \end{array}$ & $\begin{array}{l}\text { 1. Terwujudnya ketahanan } \\
\text { pangan } \\
\text { 2. Meningkatnya } \\
\text { ketenteraman, ketertiban } \\
\text { umum, dan perlindungan } \\
\text { masyarakat } \\
\text { 3. Terwujudnya } \\
\text { perlindungan sosial bagi } \\
\text { seluruh kelompok di } \\
\text { masyarakat }\end{array}$ & $\begin{array}{l}\text { Indeks ketahanan pangan } \\
\text { 1. Persentase angka } \\
\text { kriminalitas yang } \\
\text { tertangani } \\
\text { 2. Persentase bencana di } \\
\text { KRB }\end{array}$ \\
\hline
\end{tabular}




\begin{tabular}{|c|c|c|c|}
\hline \multirow{7}{*}{ Misi 1} & Tujuan & Sasaran Strategis & Indikator Sasaran Strategis \\
\hline & \multicolumn{2}{|c|}{ Apa yang ingin diubah } & Dampak yang diinginkan \\
\hline & & \begin{tabular}{ll} 
4. & \multicolumn{2}{l}{ Meningkatnya } \\
kesadaran masyarakat \\
terhadap \\
budaya
\end{tabular} & $\begin{array}{l}\text { 1. Persentase Angka } \\
\text { PMKS } \\
\text { 2. Persentase kemiskinan }\end{array}$ \\
\hline & & & Indeks gotong royong \\
\hline & \multirow{3}{*}{$\begin{array}{l}\text { Pemberdayaan } \\
\text { masyarakat, } \\
\text { pengarusutamaan } \\
\text { gender dan } \\
\text { perlindungan anak }\end{array}$} & $\begin{array}{lr}\text { Meningkatnya } & \text { kapasitas } \\
\text { pemberdayaan } & \text { kelompok } \\
\text { masyarakat } & \end{array}$ & $\begin{array}{l}\text { Status desa tertinggal } \\
\text { Jumlah prestasi pemuda di } \\
\text { berbagai kompetisi di } \\
\text { tingkat nasional maupun } \\
\text { internasional }\end{array}$ \\
\hline & & $\begin{array}{l}\text { Terwujudnya pemberdayaan } \\
\text { gender }\end{array}$ & $\begin{array}{l}\text { Indeks pemberdayaan } \\
\text { gender } \\
\text { Indeks pembangunan gender }\end{array}$ \\
\hline & & $\begin{array}{l}\text { Meningkatnya perlindungan } \\
\text { perempuan dan anak }\end{array}$ & $\begin{array}{l}\text { Penyelesaian pengaduan } \\
\text { tindak kekerasan terhadap } \\
\text { perempuan dan anak serta } \\
\text { kasus perdagangan manusia }\end{array}$ \\
\hline
\end{tabular}

sumber: Ranwal RPJMD KBB 2018-2023

Misi ke-1 dari Pemerintah Bandung Barat seperti yang tertera dalam RPJMD menaruh perhatian pada peningkatan kapasitas sumber daya manusia. Peningkatan kualitas sumber daya manusia merupakan investasi mahal dan jangka panjang. Peningkatan kualitas manusia tersebut dapat dicapai dengan menyediakan layanan pendidikan, kesehatan dan layanan dasar lainnya bagi seluruh masyarakat Bandung Barat. Harapannya, dengan kualitas manusia yang baik maka pembangunan Bandung Barat akan baik dan berkelanjutan (RPJMD KBB, 2018: 212). Tujuan misi pertama seperti yang tertera pada tabel di atas secara spesifik menyuratkan bahwa pemberdayaan masyarakat (perempuan) menjadi salah satu aspek yang perlu diprioritaskan dengan memperhatikan indikator sasaran strategis, yakni indeks pemberdayaan gender dan indeks pembangunan gender.

Aktivitas perempuan dalam kegiatan ekonomi-produktif merupakan komponen dari indeks pemberdayaan gender dengan memperhatikan indikator sumbangan pendapatan perempuan terhadap pendapatan rumah tangga. Akan tetapi, kegiatan mereka tidak jarang kurang mendapat perhatian dari pemerintah (Tambunan, 2017). Padahal pemerintah telah memiliki kerangka peraturan -dan anggaran- untuk memberdayakan kaum perempuan, yakni pembekalan berupa pengetahuan, keterampilan, pembinaan. Kontribusi dan peran perempuan di dalam 
aktivitas ekonomi perlu mendapat perhatian. Di Kabupaten Bandung Barat, 78\% pelaku UMKM berjenis kelamin perempuan (Diskop UKM KBB, 2019) dan mereka menyumbang 32,94\% terhadap pendapatan rumah tangga di KBB (BPS jabar, 2018). Berdasarkan data dan fakta tersebut, muncul pertanyaan mengenai siapakah aktor yang 'berhak' mengambil porsi lebih besar dalam hal pemberdayaan perempuan dalam konteks TPB?

\section{B. Tantangan Pemda KBB dalam melaksanakan TPB}

Keberhasilan suatu agenda tidak bisa dilepaskan dari semua pihak yang ikut terlibat di dalamnya. Upaya pencapaian target TPB menjadi prioritas pembangunan nasional, yang memerlukan sinergi kebijakan perencanaan di tingkat nasional, di tingkat provinsi maupun di kabupaten/kota. Target-target TPB di tingkat nasional telah sejalan dengan Rencana Pembangunan Jangka Menengah Nasional (RPJMN) 2015-2019 dalam bentuk program, kegiatan dan indikator yang terukur serta indikasi dukungan pembiayaannya. TPB merupakan penyempurnaan dari Tujuan Pembangunan Milenium (Millennium Development Goals/MDGs) yang lebih komprehensif dengan melibatkan lebih banyak negara, baik negara maju maupun berkembang, memperluas sumber pendanaan, menekankan pada hak asasi manusia, inklusif dengan pelibatan organisasi kemasyarakatan (ormas) dan media, filantropi dan pelaku usaha, serta akademisi dan pakar (Pedoman Penyusunan RAN TPB,Bappenas 2017)

Tugas pemerintah sebagai fasilitator seringkali dihadapkan pada regulasi yang memungkinkan percepatan pencapaian TPB menjadi terhambat. Dalam wawancara dengan Kepala Bidang UMKM KBB, penulis mendapati beberapa hal yang menjadi tantangan pemerintah dalam menjalankan program pemberdayaan perempuan dalam kaitannya dengan UMKM dan TPB. Pertama, pemerintah belum bisa menjangkau seluruh pelaku usaha yang jumlahnya besar. Dari data terakhir yang dihimpun berdasarkan data pengajuan BPUM (Bantuan Produktif Usaha Mikro), terdapat lebih dari 140 ribu pemohon ${ }^{1}$ yang mana kurang dari separuhnya

\footnotetext{
${ }^{1}$ wawancara dilakukan pada akhir Desember 2020, tidak lama berselang setelah momen pengajuan BPUM
} 
(20 ribu-an) terdaftar di dinas dan hanya kurang lebih 1000-an UMKM yang tergolong kompeten (berdasarkan indikator yang dilihat dari aspek produksi, pemasaran, sdm dan legalitas). Dari jumlah tersebut, pelaku usaha berjenis kelamin perempuan lebih banyak dibandingkan dengan jumlah pelaku usaha laki-laki. Kedua, keterbatasan anggaran. Ketiadaan pos khusus bagi perempuan yang melakukan aktivitas ekonomi-produktif mengakibatkan tidak adanya porsi yang memang diperuntukkan bagi mereka yang secara langsung terlibat dalam kegiatan produksi. Padahal, sebagian besar pelaku UMKM, khususnya pelaku mikro didominasi oleh kaum perempuan sebagaimana disebutkan sebelumnya di atas. Ketiga, koordinasi antar lembaga/dinas belum terjalin optimal. Kerja sama lintas sektoral sebenarnya dapat dilakukan misalnya bidang UMKM bekerja sama dengan Dinas Pengandalian Penduduk, Keluarga Berencana, Pemberdayaan Perempuan dan Perlindungan Anak. Akan tetapi hal ini belum berjalan. Persoalan koordinasi sebenarnya bukan saja menjadi tantangan pemerintah di daerah, melainkan menjadi pekerjaan rumah bagi pemerintah pusat.

Persoalan dan tantangan yang dihadapi pemerintah daerah sekilas terdengar klasik namun memang demikian adanya. Padahal, jika dicermati lebih dalam terdapat berbagai saluran untuk mengakomodir pihak-pihak yang berkepentingan khususnya dalam wacana TPB (Idowu, Schmidpeter, Lu, 2018)

\section{Peran UMKM dalam pencapaian TPB}

Peran UMKM dalam memberikan sumbangan pertumbuhan ekonomi nasional tidak terlepas dari sifat UMKM yang agile dan adaptif terhadap perubahan lingkungan. Struktur dan pola UMKM yang lebih sederhana dibandingkan dengan perusahaan besar memberikan keuntungan dalam hal fleksibiltias dan ketahanan mereka dalam menghadapi situasi yang berubah secara tiba-tiba. Contohnya ketika Indonesia dilanda krisis moneter medio 1997-1999 (Singgih, 2007) (Tambunan, 2017). Akan halnya kondisi pada saat terjadi krisis, kelincahan UMKM dalam mengubah perilakunya juga terjadi ketika pandemik Covid-19. Kebijakan pemerintah untuk sementara membatasi aktivitas di awal terjadi pandemi mengakibatkan lumpuhnya perekonomian nasional. Hal ini berdampak pada 
sebagian besar UMKM di Bandung Barat yang juga kesulitan dalam hal memasarkan produknya (ABDSI, 2020). Namun demikian, tantangan ini justru disambut oleh UMKM dengan mengembangkan metode pemasaran melalui platform daring. Metode ini dilakukan UMKM dalam waktu yang hampir bersamaan di seluruh wilayah Indonesia baik dilakukan secara mandiri, swadaya bersama komunitasnya, maupun melalui program pemerintah.

Dalam konteks ini penulis berpandangan bahwa struktur perekonomian nasional yang ditopang oleh para pelaku usaha mikro, kecil dan menengah memiliki potensi dan prospek yang cerah jika dikelola secara kompeten. Pengelolaan yang kompeten tidak terbatas pada pelaku usaha sebagai subjek, melainkan ditujukan pula untuk para pemangku kepentingan termasuk pemerintah di dalamnya. Sedikitnya terdapat tiga potensi yang dapat dikontribusikan UMKM dalam upaya mengimplementasikan TPB. Pertama, kontribusi terhadap GDP. UMKM merupakan kontributor utama dalam perumbuhan ekonomi diantara negra-negara anggota OECD dengan rata-rata menyumbangkan 33\% dari PDB di negara berkembang dan bahkan bisa mencapai lebih dari setengah pendapatan PDB di banyak negara (OECD, 2017). Sementara di Indonesia, UMKM berkontribusi atas 61,07\% dari pembentukan PDB (Renstra Kemenkop UKM, 2020).

Kedua, penyerapan tenaga kerja. Keberadaan UMKM biasanya terkonsentrasi di sektor berketerampilan rendah dan padat karya, seperti manufaktur ringan dan sektor jasa. Meskipun UMKM tidak memberikan upah yang sesuai dengan standar dan tidak sebanding dengan risiko pekerjaan, tingkat penyerapan tenaga kerja dari sektor UMKM cukup tinggi. Jika didukung dengan lebih baik, UMKM berpotensi untuk mempromosikan standar kerja yang layak dan menyediakan kesempatan kerja yang layak, sebagaimana sesuai dengan ketentuan ILO (UN-DESA, 2020). Dukungan yang dimaksud termasuk menciptakan kerangka kebijakan dan peraturan yang lebih memungkinkan UMKM untuk meningkatkan kapasitas khususnya dalam pengelolaan SDM. Kontribusi penyerapan tenaga kerja UMKM berdasarkan data yang diolah Kementerian Koperasi dan UKM sebanyak 116,97 juta orang atau sebesar 97\% dari total tenaga kerja sebanyak 120,598 juta orang (Renstra Kemenkop UKM, 2020). Kondisi ini 
tentu menguntungkan Indonesia karena seperti yang telah disebutkan sebelumnya bahwa UMKM memiliki kemampuan untuk beradaptasi dalam situasi yang cepat berubah. Dengan jumlah penduduk yang besar dan keterbatasan lapangan pekerjaan, keterlibatan UMKM dalam hal penyerapan tenaga kerja menjadi semakin relevan. Akan tetapi, kemampuan ini perlu didukung oleh kemapanan cara berpikir yang tentu saja melibatkan pemerintah selaku pemangku kepentingan dan pemegang regulasi. Salah satu cara yang bisa dilakukan untuk mengakomodir hal ini, misalnya dengan menyediakan pelatihan berbasis kompetensi bagi pengelola UMKM dan/atau tenaga kerja yang terlibat di sektor UMKM.

Ketiga, akses pasar dan keuangan. Akses pasar dan pembiayaan juga menjadi hal yang krusial bagi UMKM. Ketidakmampuan UMKM dalam mengakses lembaga keuangan, misalnya perbankan, disebabkan belum terbiasanya mereka menerapkan standar administrasi pencatatan keuangan yang mana hal ini merupakan salah satu pra-syarat dari perbankan. Dengan kata lain tidak sedikit UMKM yang belum bankable. Keluhan dan kendala UMKM biasanya menyangkut permodalan. Padahal, modal (capital) dapat diakses dengan mudah apabila UMKM mendapatkan edukasi yang cukup mengenai hal ini. Tidak hanya melalui lembaga perbankan, UMKM sebetulnya masih bisa mengakses melalui lembaga lain, seperti koperasi, CSR bahkan mencari investor. Akibat kurangnya modal, mereka kerapkali kesulitan mengembangkan usahanya. Dalam beberapa kasus di Kabupaten Bandung Barat, pelaku usaha mikro yang sedang mengembangkan usahanya menghadapi kenyataan bahwa mereka tidak dapat membuka akses pasar baru akibat kurangnya modal dan lambannya perputaran uang sehingga mereka memilih menunda atau bahkan tidak jadi membuka jalur pemasaran baru. Apabila UMKM diberikan kemudahan dalam mengakses modal dan bisa lebih jauh dalam melakukan penetrasi pasar, maka penyerapan dan perputaran uang di dalam negeri akan semakin cepat.

\section{Program Sekolah Ibu Hebat}

Pada 9 November 2019, Baitul Maal Hidayatullah (BMH) menginisiasi sebuah program di Kabupaten Bandung Barat yang dinamakan Sekolah Ibu Heba 
(SIH)t. BMH merupakan lembaga amil zakat nasional (laznas) yang bergerak dalam penghimpunan dana zakat, infaq, sedekah, wakaf dan hibah berikut dana sosial kemanusiaan dan Corporate Social Responsibility (CSR) perusahaan, dan melakukan distribusi melalui program pendidikan, dakwah, sosial kemanusiaan dan ekonomi secara nasional. Dalam program ini, BMH menggandeng PT. Paragon Technology and Innovation. Pembukaan kegiatan yang dilaksanakan di Hotel Mason Pine Kota Baru Parahyangan dihadiri oleh para petinggi BMH, PT. Paragon, Kepala Dinas Koperasi dan UKM Kabupaten Bandung Barat, dan Ketua Forum UMKM Kabupaten Bandung Barat. Kegiatan pemberdayaan masyarakat melalui program Sekolah Ibu Hebat (SIH) ditujukan untuk menjamin kehidupan masyarakat menjadi lebih baik. Program ibu hebat adalah program komprehensif mulai dari pelatihan, pembentukan kelompok, pembinaan, pendampingan, pemasaran paripurna hingga pemberian modal usaha. Di Bandung Barat, kegiatan ini diikuti oleh 100 peserta perempuan yang seluruhnya merupakan pelaku UMKM.

Program yang telah dijalankan BMH sejak tahun 2017 ini memfokuskan kegiatannya pada aktivitas ekonomi-produktif yang melibatkan kaum perempuan sebagai tulang punggung keluarga -yang berperan sebagai ibu sekaligus ayah. Sampai dengan tahun 2019, program ini dilaksanakan di 5 kota berbeda : Depok, Bekasi, Jakarta, Bandung Barat, dan Surabaya di mana Bandung Barat merupakan titik keempat.

Acara Pembukaan Program Sekolah Ibu Hebat di Kabupaten Bandung Barat

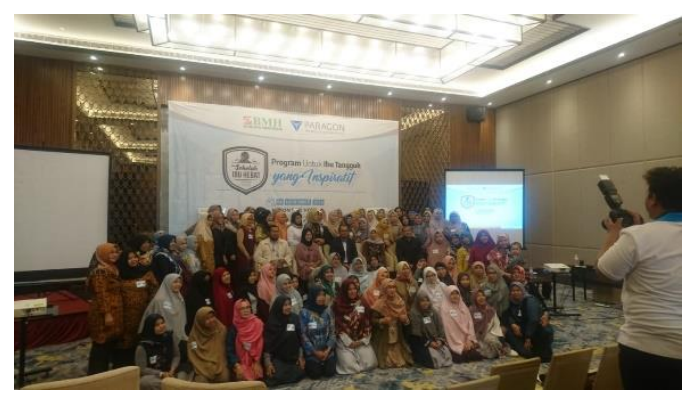

sumber : dokumentasi pribadi

Dalam wawancara dengan para pengurus BMH, baik tingkat provinsi Jawa Barat -yang bertanggungjawab langsung terhadap penyelenggaraan kegaitan SIH di 
KBB- maupun tingkat pusat, penulis mendapati sedikitnya tiga temuan dari program SIH yang terkait dengan TPB. Pertama, kegiatan ekonomi produktif. Sebagai lembaga non-pemerintah yang mengelola dana yang bersumber dari masyarakat, BMH memiliki kewajiban untuk mendistribusikan kembali dana yang terhimpun untuk dimanfaatkan oleh masyarakat melalui program pendidikan, dakwah, sosial kemanusiaan dan ekonomi. Outcome dari program ini yakni terciptanya para perempuan tangguh yang mampu menjalankan kegiataan ekonomi produktif secara mandiri. Dengan kata lain, para peserta yang mengikuti program SIH bertanggung jawab penuh atas kegiatan ekonomi yang mereka lakukan. Mereka secara berkesinambungan diberikan pelatihan dan pendampingan selama kurang lebih 1 tahun, meliputi pengetahuan kewirausahaan, manajemen produksi, distribusi, hingga pemasaran. Kedua, pemberdayaan perempuan. Latar belakang BMH meluncurkan program SIH didasari kepedulian terhadap kaum perempuan yang berjuang untuk "sekadar" bertahan hidup. Melalui program ini diharapkan akan meningkatkan kesejahteraan mereka yang menjadi tulang punggung keluarga. Mereka yang menjadi peserta, diberikan pelatihan dan pengetahuan tentang kewirausahaan. Disamping itu, mereka juga diberikan pembekalan dan pendampingan secara intensif oleh tenaga pendamping yang siap memberikan mentoring selama program ini berlangsung. Nantinya, para kaum perempuan yang telah dibina tidak lagi berpandangan bahwa kegiatan bisnis yang mereka lakukan hanya sekadar untuk bertahan hidup, melainkan bisnis yang dapat bermanfaat bagi diri sendiri dan orang lain. Ketiga, pengurangan kemiskinan. Seiring dengan meningkatnya kesejahteraan para penerima manfaat program ini, tingkat kemiskinan dapat dikurangi. Dampak jangka panjang yang diharapkan adalah penyerapan tenaga kerja oleh UMKM yang dijalakan oleh peserta SIH akan mampu memberikan efek pengganda (multiplier effect) tidak hanya bagi peserta melainkan bagi lingkungan sekitar dan bermanfaat bagi masyarakat. 
Pembekalan Materi Pelatihan dan Sosialisasi Titik Kritis Halal oleh Ir. Dina Sudjana (Ketua Pusat Halal Salman ITB)

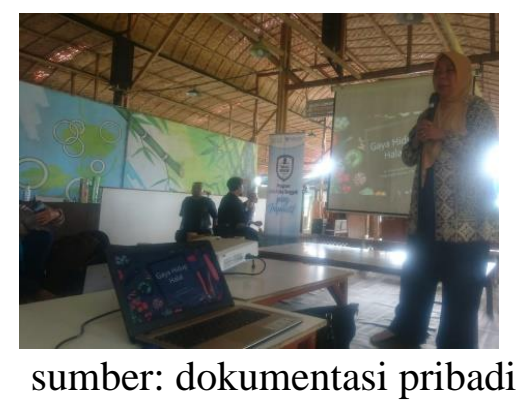

Selain tiga temuan di atas, program SIH di KBB juga memiliki corak berbeda jika dibandingkan dengan program SIH yang telah diselenggarakan BMH di kota lain. Di Bekasi misalnya, BMH bekerja sama dengan masjid-masjid atau lembaga lain yang dapat membantu memberikan pelatihan dan biasanya mereka diberikan keterampilan tertentu, contohnya mengolah makanan, membuat kerajinan dan sebagainya. Sementara program SIH di KBB merupakan program yang mengombinasikan antara pelaku usaha yang telah menjalankan usaha (60 orang) dan mereka yang baru akan menjalankan usaha (40 orang). Hal ini dilakukan agar terjadi kolaborasi dan kerja sama di antara mereka sehingga tujuan program ini dapat tercapai. Di akhir program SIH, BMH juga mendorong para peserta untuk membentuk atau bergabung dengan koperasi sebagai sarana pembinaan yang berkelanjutan. Uniknya, koperasi yang dimaksud merupakan koperasi penyedia bahan baku produksi sehingga mereka cukup bekerja sama dengan koperasi untuk menyuplai keperluan produksi mereka.

\section{E. Relasi kerja penyelenggaraan program Sekolah Ibu Hebat}

Program Sekolah Ibu Hebat yang digagas BMH merupakan suatu terobosan mengingat program pemberdayaan ekonomi-produktif yang dibuat secara khusus untuk perempuan belum banyak dilaksanakan, terkhusus di Kabupaten Bandung Barat. Kepala Bidang UMKM Kabupaten Bandung Barat, menyatakan bahwa program ini dapat menjadi penggerak bagi terselenggaranya program serupa yang diinisiasi oleh lembaga swasta lainnya. Program pemberdayaan perempuan dan UMKM tidak mendapat porsi khusus jika mengacu pada program Dinas Koperasi 
dan UKM. Akan tetapi, program semacam ini seharusnya dapat berjalan melalui kerja sama lintas sektor ditambah dukungan lembaga non-pemerintah.

Penulis menilai bahwa Program Sekolah Ibu Hebat bukan hanya sebagai terobosan melainkan sebagai jembatan yang mempertemukan kepentingan yang berbeda. Dalam konteks ini, penulis beranggapan bahwa TPB dapat tercapai apabila stakeholders mampu berkolaborasi untuk tujuan jangka panjang. Keterlibatan Forum UMKM sebagai sarana komunikasi para pelaku usaha dan dukungan penuh dari Dinas Koperasi dan UKM KBB memberikan pemahaman bahwa relasi kerja antar lembaga menjadi suatu hal yang perlu dipertahankan. Menariknya, penulis menemukan bahwa relasi kerja atau kemitraan antara kedua lembaga tersebut saling melengkapi. Dalam kasus Sekolah Ibu Hebat, Forum UMKM menjadi lembaga yang pertama diajak berdiskusi oleh BMH mengenai program tersebut dengan dinas sebagai 'pihak yang hanya mengetahui' kegiatan tersebut. Akan tetapi, hal ini tidak mengurangi perhatian dinas karena dengan adanya program pemberdayaan ekonomi-produktif membuka peluang bagi dinas membuat program lintas sektor yang memberikan perhatian pada pemberdayaan perempuan dan ekonomiproduktif, sebagaimana pembahasan dalam tulisan ini. Lebih jauh, persoalan Pengarusutamaan Gender (PUG) juga telah menjadi perhatian Kementerian Koperasi dan UKM RI sebagaimana Instruksi Presiden No 9 Tahun 2000 tentang Pengarusutamaan Gender dalam Pembangunan Nasional (Kemenkop UKM, 2019)

\section{KESIMPULAN}

Keterlibatan berbagai aktor dalam upaya mencapai TPB, semestinya menjadi suatu keniscayaan mengingat banyaknya indikator yang perlu dipenuhi. Keberhasilan dalam memenuhi indikator-indikator ini memerlukan upaya yang melibatkan semua pihak, termasuk individu itu sendiri. Dari studi kasus yang terjadi di Kabupaten Bandung Barat, penulis mengambil beberapa kesimpulan. Pertama, program SIH memberikan pemahaman baru mengenai capaian target TPB yang tidak bisa diwujudkan tanpa kerja sama dari berbagai pihak. Hal ini sedikit klise namun kenyataannya proses untuk menyamakan persepsi di antara para pihak di lapangan tidak mudah. Kerangka peraturan TPB berupa Perpres hingga Perda / 
RPJPD yang dapat dijadikan acuan dalam perumusan kebijakan / program kerapkali terhambat oleh, misalnya, ketiadaan anggaran. Kehadiran Forum UMKM sebagai mitra kerja dinas dan keterbukaan BMH untuk menerima masukan menjadikan program ini dapat terlaksana. Kedua, keberhasilan program SIH dalam mewujudkan TPB memerlukan waktu dan proses yang tidak sebentar. Meskipun tidak terlibat secara langsung lagi setelah berakhirnya program, BMH terus memberikan dukungan dan pembinaan melalui supervisi yang didelegasikan baik oleh forum UMKM melalui koperasi yang telah ada maupun oleh dinas. Ketiga, keterlibatan perempuan dalam pembangunan ekonomi nasional menjadi hal yang tidak terelakkan lagi. Aktivitas ekonomi-produktif nyatanya bisa dijalankan kaum perempuan bahkan dari rumah sekalipun. Hal ini akan berdampak pada tersedianya akses pembiayaan yang selama ini menjadi tantangan pelaku usaha mikro, terkhusus usaha yang dijalankan oleh perempuan. Dengan adanya koperasi yang menyediakan bahan baku produksi, sekurang-kurangnya dapat membantu pelaku usaha untuk mengatasi permasalahan ketiadaan modal untuk memulai usahanya.

\section{DAFTAR PUSTAKA}

Agarwal, B. (2018). Gender equality, food security and the sustainable development goals. Current opinion in environmental sustainability, 34, 26-32.

Badan Perencanaan Pembangunan Nasional, diakses pada 20 Desember 2020, http://sdgs.bappenas.go.id/tentang/

Badan Pusat Statistik Jawa Barat, "Jumlah Penduduk Menurut Jenis Kelamin 20152019”, diakses pada 20 Desember 2020, https://jabar.bps.go.id/

Baden, S., \& Reeves, H. (2000). Gender and development: Concepts and definitions (p. 28). Bridge.

Brinkerhoff, J., Smith, S., \& Teegen, H. (Eds.). (2007). NGOs and the Millennium Development Goals: citizen action to reduce poverty. Springer.

Blackburn, S. (2004). Women and the state in modern Indonesia. Cambridge University Press

Duflo, E. (2012). Women empowerment and economic development. Journal of Economic literature, 50(4), 1051-79

Jurnal Academia Praja Volume 4 Nomor 2 - Agustus 2021 
Edwards, J., \& Cornwall, A. (Eds.). (2014). Feminisms, empowerment and development: Changing womens lives. Zed Books Ltd..

Ellis, A., Kirkwood, D., \& Malhotra, D. (2010). Economic opportunities for women in the East Asia and Pacific region. World Bank Publications.

Fielden, S. L., \& Davidson, M. J. (2006). International handbook of women and small business entrepreneurship. Women in Management Review.

Ford, M., \& Parker, L. (Eds.). (2008). Women and work in Indonesia (Vol. 5). Routledge.

Harcourt, W. (Ed.). (2016). The Palgrave handbook of gender and development: Critical engagements in feminist theory and practice. Springer

Horrell, S., Johnson, H., \& Mosley, P. (Eds.). (2008). Work, female empowerment and economic development. Routledge.

Idowu, S. O., Capaldi, N., Fifka, M. S., Zu, L., \& Schmidpeter, R. (Eds.). (2015). Dictionary of corporate social responsibility: CSR, sustainability, ethics and governance. Springer.

Lacey, A. (2017). Women, Urbanisation and Sustainability. Basingstoke, Palgrave Macmillan.

Laporan Pengarusutamaan Gender Kemenkop UKM Republik Indonesia Tahun 2019

Nussbaum, M. C. (2001). Women and human development: The capabilities approach (Vol. 3). Cambridge University Press.

OECD (2017). Enhancing the Contributions of SMEs in a Global and Digitalised Economy.

OECD (2019), Enabling Women's Economic Empowerment: New Approaches to Unpaid Care Work in Developing Countries, OECD Publishing, Paris, https://doi.org/10.1787/ec90d1b1-en.

Pedoman Penyusunan Rencana Aksi Nasional TPB,Bappenas Tahun 2017

Pedoman Teknis Penyusunan Rencana Aksi Nasional TPB,Bappenas Tahun 2017

Peraturan Gubernur Jawa Barat No 18 Tahun 2018 Tentang Rencana Aksi Daerah (RAD) Tujuan Pembangunan Berkelanjutan/Sustainable Development Goals Daerah Provinsi Jawa Barat 
Peraturan Presiden No 59 Tahun 2017 Tentang Pelaksanaan Pencapaian Tujuan Pembangunan Berkelanjutan

Pusat Data UMKM Crisis Centre, Asosiasi BDS Indonesia Korwil Jabar, 2020

Pusat Data UMKM Dinas Koperasi dan UKM Kabupaten Bandung Barat, 2019

Rancangan Awal RPJMD Kabupaten Bandung Barat 2018-2023

Rencana Strategis Kemenkop UKM Republik Indonesia Tahun 2020

Scheyvens, R., Banks, G., \& Hughes, E. (2016). The private sector and the SDGs: The need to move beyond 'business as usual'. Sustainable Development, 24(6), 371-382.

Singgih, M. N. (2007). Strategi Penguatan Usaha Mikro Kecil Menengah (UMKM) Sebagai Refleksi Pembelajaran Krisis Ekonomi Indonesia. Jurnal Ekonomi Modernisasi, 3(3), 218-227.

Tambunan, T. T. H. (2017). Women entrepreneurs in MSEs in Indonesia: their motivations and main constraints. JWEE, (1-2), 56-86

UN Declaration on the Right to Development, 1986

UN-DESA, 2020, Micro-, Small and Medium-sized Enterprises (MSMEs) and their role in achieving the Sustainable Development Goals (SDGs), United Nations Departement of Economic and Social Affairs 